\title{
Corrigendum: Investigating supply chain sustainability in South African organisations
}

\section{Authors:}

Gabrielle Niehaus ${ }^{1}$

Heinrich W. Freiboth ${ }^{1}$

Leila L. Goedhals-Gerber ${ }^{1}$ (D)

\section{Affiliations:}

${ }^{1}$ Department of Logistics,

Stellenbosch University,

South Africa

\section{Corresponding author:}

Leila Goedhals-Gerber,

leila@sun.ac.za

Dates:

Published: 10 Dec. 2018

How to cite this article:

Niehaus, G., Freiboth, H.W. \& Goedhals-Gerber, L.L., 2018,

'Corrigendum: Investigating supply chain sustainability in South African organisations', Journal of Transport and Supply Chain Management 12(0), a437. https://doi. org/10.4102/jtscm.v12i0.437

\section{Copyright:}

(C) 2018. The Authors. Licensee: AOSIS. This work

is licensed under the

Creative Commons

Attribution License.
In the version of this article published earlier, the surname of the second author was inadvertently misspelt as 'Feiboth'. The second author's surname should have appeared as 'Freiboth' throughout the author list and 'How to cite' information. This correction does not alter the study's findings of significance or overall interpretation of the study results. The author apologises for any inconvenience caused. 


\section{Investigating supply chain sustainability in South African organisations}

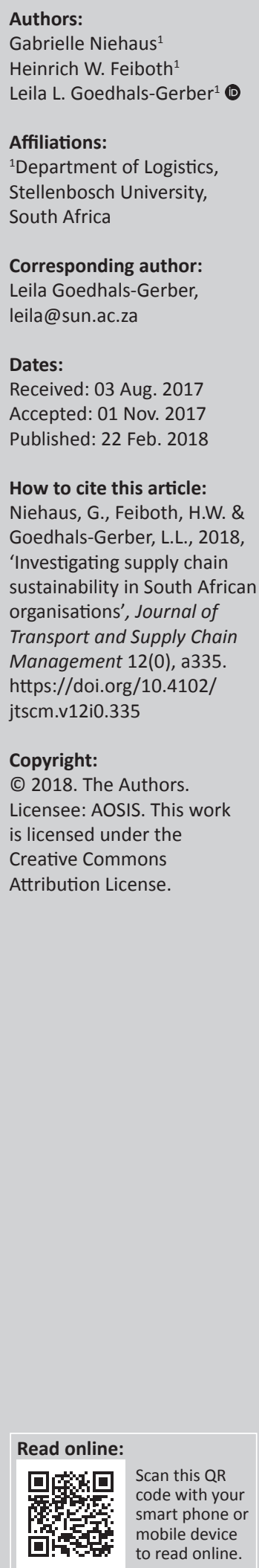

\section{Copyright:}

(C) 2018. The Authors. Licensee: AOSIS. This work is licensed under the Creative Commons Attribution License.

Background: The need for sustainable supply chain management has become a necessity given the growing impact of climate change and global warming. The South African (SA) government is planning to implement a carbon tax in the future, which will present financial challenges for organisations already facing social and environmental difficulties.

Objectives: The main objective of this article was to investigate the current sustainability reporting practices in supply chains of SA organisations. The focus was specifically on the supply chain sustainability practices of organisations listed in selected sectors on the Johannesburg Stock Exchange (JSE). A secondary objective was to investigate preparation efforts by SA companies for the impending carbon tax.

Method: Data collected from sustainability and integrated annual reports of organisations in the sample were analysed using non-parametric statistical tests to compare sectors on the JSE and to compare companies listed on the socially responsible investment (SRI) Index with those that are not.

Results: The results showed that there is insufficient data for some of the sectors; however, there are differences in the supply chain and sustainability practices for the remaining sectors. There are also differences in these practices between SRI and non-SRI companies. The research also showed that companies are discussing important concepts relating to the implementation of the impending carbon tax.

Research impact: SA organisations need to increase their focus on sustainable supply chain practices. Further investigation into the preparation efforts of companies to reduce their emissions and/or footprint and mitigate the impact of the impending carbon tax is necessary.

\section{Introduction}

The trend towards sustainable practices is on the rise globally as governments, organisations and the public realise the increasingly negative environmental impact anthropogenic activities have on the environment (Heal 2012). Subsequently, environmental issues have become significant causes for concern and the environmental dimension has become an integral aspect in organisational strategy, planning and operations. Supply chains are under immense pressure from multiple stakeholder groups to seek solutions that positively impact both economic and environmental performance, and they are constantly developing, implementing and improving operations to ensure that they mitigate their negative environmental impact and are socially responsible (Handfield, Sroufe \& Walton 2005; Ho \& Lin 2008).

Supply chain sustainability has been researched thoroughly across the globe; however, less research has been conducted on the disclosure of sustainable supply chain management practices in sustainability reports, in particular for developing countries such as South Africa (Morhardt 2009). This article aims to investigate the current supply chain sustainability reporting practices of listed organisations in South Africa and to compare practices between socially responsible investment (SRI) and non-SRI indexed companies. In addition, it investigates preparation efforts by South African companies for the impending carbon tax. The remainder of this article is organised as follows: the next section provides the problem statement and research objectives followed by a literature review. Then, the article provides a description of the research methodology that was used for the research and a discussion of the results and findings of the study. The final two sections present the conclusions and implications for future research on this topic.

Note: This article is partially based on the author's thesis for the degree of Master of Commerce at the Faculty of Economics and Management Sciences, Stellenbosch University, South Africa, with supervisor Mr H.W. Freiboth and co-supervisor Dr L.L. GoedhalsGerber, received March 2016, available here: http://scholar.sun.ac.za/bitstream/handle/10019.1/98468/niehaus_investigation_2016. pdf?isAllowed $=y \&$ sequence $=2$ 


\section{Problem statement}

Sustainable development has become essential as a result of the impact of climate change and global warming on organisations across the globe. Traditionally, the focus in business has been on financial performance and maximising profits (Tran 2015). However, there has been a shift in recent years towards focusing on environmental performance and sustainability of the triple bottom line (Jamali, Mezher \& Bitar 2006). It is important for organisations to understand the negative impact their operations have on the environment and the potential of supply chains to contribute to reducing costs and harmful emissions. This article investigates the current supply chain sustainability reporting practices of organisations listed on the Main Board of the Johannesburg Stock Exchange (JSE) and explores the readiness of South African companies for the impending carbon tax.

\section{Research objectives}

The main objective of this article is to investigate current sustainability reporting practices in South African organisations, focusing on selected sectors of the JSE and to compare practices between SRI and non-SRI indexed companies. A secondary objective is to investigate preparation efforts by South African companies for the impending carbon tax.

\section{Literature review}

\section{Defining sustainability}

According to Van Zyl (2013), the term 'sustainability' is at risk of becoming overused and meaningless. Gray (2010:49) argues that through replication the term 'sustainability' is starting to become tantamount to activities rather than being indicative of what a truly sustainable system would look like (Fisher-Kowalski 2011:153). According to Gray (2010:48), scientific research in the field has shown that the majority of business reporting on sustainability and a significant percentage of the business activities that are designed to promote sustainability are not closely related to sustainability.

Sustainability is often implicitly defined with little international agreement on one concrete definition. Although the definitions for sustainability are often relatively vague, a number of themes emerge when defining sustainability that relate to maintaining economic prosperity, balancing population growth and meeting societal needs, in addition to preserving natural resources and minimising negative environmental impacts (Brown et al. 1987). From this it can be deduced that sustainability relates to social well-being, financial success in meeting desired living standards and a healthy, balanced natural environment. For the purpose of this article, sustainability is defined as 'the ability to meet current social, environmental and economic needs without negatively impacting the ability of future generations to meet their social, environmental and economic needs'.

\section{Driving forces for sustainability in supply chains}

Driving forces behind sustainable practices in organisations can either be individuals, groups or events inside the organisation (internal driving forces) or outside of the organisation (external driving forces) (Van Marrewijk \& Werre 2003). With regard to internal driving forces, there are a number of strategic drivers for sustainability including enhancing the reputation of the brand or organisation, new market and product opportunities and aligning sustainable practices with overarching strategic objectives (Bonini, Görner \& Jones 2010). Forward-thinking organisations see opportunities to create value and develop and maintain strategic competitive advantages through the development and implementation of supply chain sustainability (Kumar, Teichman \& Timpernagel 2011).

Global warming and climate change are prominent external driving forces that cause organisations to address the negative impact their operations have on the natural environment. Rising fuel prices are driving sustainable practices in organisations as they find ways to minimise transport and utilise renewable energy in place of fossil fuels such as oil and coal (World Economic Forum 2009). The supply chain itself drives sustainable practices to develop efficiencies, minimise waste and reduce costs and emissions in addition to supporting the sustainability objectives of other supply chain members including suppliers, distributors and sales agents such as retailers (Carter \& Rogers 2008; Mefford 2011).

Higher levels of efficient and effective supply chain integration provide an additional incentive for organisations to implement environmentally conscious practices (Kumar et al. 2011). International and domestic regulation and legislation, such as the Kyoto Protocol and the carbon tax due for implementation in South Africa in the future, force organisations to adopt sustainable practices to remain competitive, or in the case of the JSE, organisations must address environmental issues as part of the listing requirements (JSE 2014).

\section{Supply chain decarbonisation}

The reduction of carbon emissions in the supply chain is known as supply chain decarbonisation. According to the World Economic Forum (2009), the most important factor in lowering carbon emissions is the reduction of non-renewable energy usage in the supply chain. The main drivers of decarbonisation include more stringent regulation and legislation, rising and unstable fuel prices and increasing consumer pressure to become more environmentally friendly (Niehaus 2016). The areas with the greatest opportunity to achieve supply chain decarbonisation are energy-efficient physical facilities, energy-efficient vehicle technologies, slowing the speed of transport through the supply chain, ensuring all networks are optimised and training and education of supply chain members and stakeholders (World Economic Forum 2009). However, the areas offering the greatest potential to reduce carbon emissions include lowcarbon sourcing in agriculture, energy-efficient vehicle technologies, slowing the speed of transport through the supply chain, low-carbon sourcing in manufacturing and packaging design initiatives (World Economic Forum 2009). 
According to Niehaus (2016), environmental performance can be improved and value can be created along a supply chain in the short term through implementing low-carbon sourcing in agricultural activities, optimising the management of networks, training and communication, packaging design initiatives and low-carbon sourcing in manufacturing activities, whilst reducing congestion and redesigning and constructing energy-efficient buildings are opportunities that are more achievable in the medium to long term. An important conclusion is that there is a wide variety of supply chain decarbonisation opportunities available, irrespective of the type of industry an organisation is in.

Although the need for the mitigation of negative supply chain environmental impacts has received significant attention, little focus has been placed on the emergence of adaptive logistics. According to Kreie and McKinnon (2010), mitigation is important to reduce the negative environmental impacts (such as carbon emissions) to ultimately attenuate the global warming process. However, the extent of damage to the natural environment will take decades to repair even if global decarbonisation and green transformation could be achieved tomorrow and as a result society as a whole needs to adapt to a new environment with a changed climate. Adaptive logistics refers to the adjustments that will be necessary to align supply chains with the changing environment to adapt to the effects of global warming and climate change (Kreie \& McKinnon 2010). There is uncertainty around what the true effects of global warming and climate change will be in the future and the extent of this change is equally unclear. The consequences of global warming will differ depending on geographic location and the resilience of the local population. Although it is unclear what the full implications of global warming will be, it is essential that supply chains prepare for any outcome and develop and implement systems that are robust and sustainable. According to Kreie and McKinnon (2010), supply chains will need to develop direct and indirect responses to climate change including implementing green logistics systems to minimise negative environmental impacts redesigning and modifying logistics networks to meet the new demands that have arisen.

\section{South African context}

South Africa, as an economic leader on the African continent, is a member of the Kyoto Protocol and has planned to implement a carbon tax (Greve 2014). This is a clear indication that the country is committed to the transition from an energy-intensive economy to a low-carbon economy. The financial implications of the tax will place financial pressure on organisations as the tax rate will be R120 (equivalent to approximately $£ 7.09, € 7.94$ or $\$ 9.24$ in June 2017) per ton of carbon dioxide $\left(\mathrm{CO}_{2}\right)$ equivalent emissions (Gordhan 2013). It is imperative that companies focus on maximising the efficiency and effectiveness of their supply chain operations to minimise the future cost implications of the tax.

\section{Implications of implementing carbon taxes in South Africa}

According to Alton et al. (2014), South Africa has the motivation to support global mitigation of carbon emissions in the long term through the introduction of a carbon tax. This opinion is shared by Winkler and Marquard (2011) who state that the South African government, economy and society should consider employing a carbon tax as part of a broad portfolio of mitigation actions to reduce carbon emissions in the long term.

In the shorter term, there are potential obstacles that South Africa could face if they do not implement the proposed carbon tax. Firstly, South Africa cannot rule out the prospect of the development of a coalition of mitigating countries that take steps to implement policies, such as Border Carbon Adjustments (BCAs) to reduce the impact of carbon emissions on the environment by imposing taxes on the carbon content of imports (and rebate domestic exporters). If employed, BCAs would disadvantage carbon intensive economies, such as South Africa, in global markets (Alton et al. 2014). A second obstacle that South African companies could potentially face in the short to medium term is the need to meet consumer demand for 'greener' products as the level of education of consumers around sustainability issues improves (Hitchcock 2012).

South Africa could take proactive steps to prevent this from happening by implementing carbon taxes in the short term, which would serve to initiate the transformation to a 'greener' economy and as a result would avoid having to rapidly reduce emissions in the future (Alton et al. 2014). In addition, current research indicates that a carbon tax would increase in price of energy generated by fossil fuels to a level that would incentivise energy generated by non-fossil fuel sources such as renewable electricity (Incite Sustainability 2009; Winkler \& Marquard 2011).

\section{South Africa's transition to a low-carbon economy}

Historically, the South African economy was driven by energy-intensive sectors such as agriculture and mining; however, there has been a shift in the economy to focus on knowledge and service in recent years (Media Club South Africa 2015). As businesses are facing increased pressure from consumers to be more aware of the environment and changing legislation from government requiring greater commitment to reducing emissions and incorporating sustainability into organisational strategy, sustainabilityrelated organisational practices are becoming increasingly important from both a voluntary and mandatory perspective (KPMG 2013). It is especially important for organisations in energy-intensive industries to make substantial changes given the significant impact of their operations on the environment (Carbon Disclosure Project [CDP] 2013a).

The implementation of the impending carbon tax has been delayed more than once. Organisations should utilise this delay to develop and improve environmentally sustainable practices and start emissions reduction programmes to make the necessary corrective adjustments before the tax is implemented. One possible opportunity is the generation of cleaner electricity through renewable energy (Incite 
Sustainability 2009; Winkler \& Marquard 2011). The carbon footprint of electricity generated from wind and solar sources is virtually zero, which will result in attractive returns at low risk and act as a hedge against future energy price increases and the implementation of the proposed carbon tax (Incite Sustainability 2009).

According to Gordhan (2013), certain organisations may face financial difficulty as a result of the carbon tax. It is, therefore, essential that companies start to focus on making operations as efficient and effective as possible to minimise the future cost implications of the tax. Tools such as carbon footprint calculators can be used to determine the total amount of direct and indirect $\mathrm{CO}_{2}$ and other greenhouse gas emissions expressed in carbon dioxide equivalent $\left(\mathrm{CO}_{2} \mathrm{e}\right)$ of a product, process, organisation or region (Minx \& Wiedmann 2007). Given the significant impact of supply chains on financial performance and greenhouse gas emissions, it is important to determine sustainable supply chain best practices to determine where improvements can be made (Kumar et al. 2011).

\section{Johannesburg Stock Exchange}

The JSE was established in 1887 and is the largest stock exchange on the African continent. It is included in the top 20 largest stock exchanges globally based on market capitalisation. Listing requirements for the JSE stipulate that companies must follow the King III corporate governance code and should publish an annual integrated report. The integrated report represents a transformation of the separate annual financial and sustainability reports to provide a holistic overview of the companies' financial, social and environmental performance (SAICA 2011).

The Global Reporting Initiative (GRI) Sustainability Reporting Guidelines are the most used reporting guidelines in South Africa. The guidelines consist of 70 assessment criteria including both general indicators and sector-specific indicators. The reason for the popularity of the GRI guidelines is because they can be used for any company, regardless of industry and size, and the assessment is comprehensive providing a standardised framework for companies to report their sustainability efforts and accomplishments to date (Kinderytė 2008).

Companies listed on the main board of the JSE are responsible for most of the JSE's market capitalisation and consist of over 300 listed companies. Sectors on the main board include basic materials, consumer goods, consumer services, financials, health care, industrials, oil \& gas and technology and telecommunications (JSE 2014). The sectors making up the majority of the JSE main board include financials, basic materials and industrials, which is in line with the sectors driving the South African economy.

With the exception of the financial sector, the sectors driving the economy are some of the most energy-intensive (InglesiLotz 2015). Organisations operating in these sectors need to ensure the efficiency and sustainability of their supply chains to ensure social, environmental and financial costs are minimised.

\section{Moving towards sustainable development}

The JSE SRI Index, currently consisting of 82 constituents, was launched in 2004 to facilitate the management of listed companies' triple bottom line performance. The particular focus of SRI in South Africa is indicative of the distinctive socioeconomic challenges faced by the country (Giamporcaro \& Pretorius 2012). The index provides a benchmark for organisations to compare and improve their current sustainability performance, and allows investors to base their analyses on a broader set of criteria (JSE 2015). According to a report compiled by the CDP, South African companies included in the JSE Top 100 are performing well with regard to sustainability reporting given that the CDP response rate for 2013 was $83 \%$ - the second highest response rate in the world. Roughly $70 \%$ of the JSE Top 100 companies are listed on the SRI Index. Disclosure in sustainability reports has improved in general, and there has also been an increase in the number of companies that have voluntarily set emissions reduction targets (CDP 2013b).

Sustainability reports are easily accessible and valuable sources of information when wanting to examine the supply chain and sustainability practices of organisations (Ellram, Kirchoff \& Tate 2009). Although it appears that sustainability reporting efforts have improved, a study undertaken by KPMG found that the level of reporting on the impact of supply chains on sustainability is still relatively low. Research conducted by Van Zyl (2013) identified that supply chain management has received limited consideration in business strategies, with $70 \%$ of the best performing companies, according to the JSE Sustainability Index, making no disclosure relating to the environmental impact of their supply chain. By including supply chain issues and opportunities in transparent integrated reports, companies will allow investors, consumers, government and the general public to know how they are managing the complex challenges associated with adapting to global warming, increasing regulations and rising consumer pressure (KPMG 2013).

Research conducted by Van Zyl (2013) identified that although many companies listed on the South African JSE are trying or claiming to be generating integrated reports, the level of integration and the understanding of what a truly integrated report is, is still very low. In addition, research by Hanks and Gardiner (2012:14) showed that few South African companies have actually included and truly comprehend the significance of environmental and societal influences in realising long-term profitability.

The integrated reporting process in South Africa is still in the developmental phase, with a large proportion of South African companies only starting to acquire procedures to measure their various impacts. There are a few South African companies who are actively striving to make use of the 
benefits of integrated reporting and the information generated in the reports could potentially lead to changes in business strategies (Van Zyl 2013).

\section{Methodology}

The design and methodology for this study are based on research undertaken by Professor James R. Stock from the University of South Florida, in collaboration with a number of researchers in various countries. The aim of the research is to investigate the supply chain sustainability practices of manufacturing, retail and service organisations through their annual sustainability reports. Results from studies in China, Thailand, the United States and Vietnam, have so far been published in refereed articles (Wang, Stock \& Li 2015), conference proceedings (Espinosa \& Stock 2017; Koshkaki, Gammelgaard \& Stock 2017; Nguyen \& Stock 2017), with additional working papers in progress. This research was adapted to suit the South African context and the sampling procedures, data collection and data analysis techniques are discussed in the remainder of this section.

The research for this article was conducted using secondary research methods to provide an analysis of the environmental sustainability practices of organisations listed on the JSE. The Internet was used to investigate company websites, annual financial reports, sustainability reports and academic articles and publications. This step was critical for this study because of the fact that very few privately owned companies are willing to disclose their annual reports on the Internet, whereas listed companies must disclose their reports as part of the listing requirements on the JSE.

The subsequent method that was utilised included the use of content analysis that was conducted on data collected from integrated annual reports and sustainability reports from company websites found on the Internet. Content analysis can be understood as the systematic observation and quantitative description of the manifest content of communication' (Babin \& Zikmund 2010:253). These documents provided the information that was needed to extract data to investigate differences between sectors and SRI Index versus non-SRI Index companies using qualitative content analysis software. Statistical analyses were performed on the data using Statistica software.

\section{Sampling procedure and data collection}

The sampling procedure that was utilised for this study began with the selection of all organisations listed on the main board of the JSE because of the online availability of their sustainability and integrated annual reports. The latest available reports for these organisations were downloaded from company websites during February 2015. For the majority of the reports (64\%), the reporting year of 2014 was used as this was the most recent reporting period where complete reports were available. However, the most recent reporting period for $32 \%$ of the companies included was 2013, and the most recent reporting period for the remaining
$4 \%$ of companies was 2012. Companies whose operations are based overseas, or that did not have reports available from 2012 to 2014, were excluded from the study.

The JSE main board consists of nine sectors; however, for the purposes of this research, consumer services was divided into two categories, namely, retailers and other consumer services. It was necessary to investigate retail organisations separately as they have extensive supply chain operations that have potentially significant environmental impacts. After performing an initial statistical analysis, four of the sectors, namely, health care, oil and gas, technology, telecommunications and other consumer service sectors were found to have insufficient data producing insignificant results. To ensure the reliability of the results, only energyintensive sectors with sufficient data to produce significant results were included in the final analyses. The remaining sectors include the basic materials (52 companies), consumer goods (20 companies), industrials (59 companies) and retailers (24 companies) sectors. The total sample size for the final analyses was 155 companies.

\section{Data analysis techniques}

The first phase of this study included a content analysis using NVivo 10 software and the second phase consisted of nonparametric statistical analyses using Statistica. The content analysis was based on an established a priori list of 32 keywords relating to supply chain management and sustainability. Thirteen keywords relating to supply chain management and 21 keywords relating to sustainability were identified based on Professor Stock's research and the literature reviewed for this study. The keywords identified in addition to Professor Stock's list relate to supply chain activities discussed in South African supply chain literature and the impending carbon tax. These keywords include 'procurement', 'sourcing', 'carbon emissions', 'carbon footprint', 'carbon tax', 'environmental management' and 'triple bottom line'. These keywords are relevant given the financial impact of supply chain activities on business, and the potential of supply chain activities to reduce negative environmental impacts, in particular carbon emissions. The 32 keywords identified for this study are presented in Table 1.

In addition to highlighting the sentences containing the keywords to provide context, the NVivo 10 software located the keywords in the reports and counted how many times each word or phrase was mentioned. The keyword frequencies obtained in the content analysis were utilised as the data inputs for the statistical analyses performed using Statistica. Keywords with less than 10 observations were excluded from the statistical analysis.

The resulting data set was found to have a skewed distribution (normality assumptions not satisfied) and non-parametric statistical tests were conducted to determine the significance of the data at a $5 \%$ level of significance. Non-parametric tests do not require normality assumptions (like, e.g. $t$ and $F$ tests) and therefore are more suitable for finding statistically 
TABLE 1: Keywords relating to supply chain management and sustainability.

\begin{tabular}{ll}
\hline Supply chain keywords & Sustainability keywords \\
\hline Inventory & Carbon emissions \\
\hline Logistics & Carbon footprint \\
Packaging & Carbon tax \\
Procurement & Energy \\
Recycling & Energy conservation \\
Refurbishment & Energy efficiency \\
Remanufacturing & Environmental management \\
Reverse logistics & Environmental performance indicators \\
Sourcing & Global Reporting Initiative (GRI) \\
Supply chain & GRI guidelines \\
Supply chain management & International Organisation for Standardisation (ISO) \\
Transportation & ISO 14000 \\
Warehousing & ISO 14001 \\
- & ISO 14001 certification \\
\hline- & Renewable energy \\
\hline- & Sustainability \\
\hline- & Sustainability framework \\
\hline- & Sustainability metrics \\
\hline & Triple bottom line \\
\hline
\end{tabular}

Source: Niehaus, G., 2016, Investigating the current supply chain sustainability reporting practices of South African organisations, Published Master's thesis, Stellenbosch University, Stellenbosch, p. 70

TABLE 2: Inclusion of supply chain-related keywords.

\begin{tabular}{lcc}
\hline Supply chain keywords & Number of companies & $\begin{array}{c}\text { Percentage of total } \\
\text { number of companies }\end{array}$ \\
\hline Inventory & 124 & 80 \\
Procurement & 123 & 79 \\
Supply chain & 107 & 69 \\
Logistics & 106 & 68 \\
Recycling & 93 & 60 \\
Sourcing & 78 & 50 \\
Packaging & 69 & 45 \\
Transportation & 57 & 37 \\
Warehousing & 44 & 28 \\
Supply chain management & 39 & 25 \\
Refurbishment & 25 & 16 \\
Remanufacturing & 3 & 2 \\
Reverse logistics & 3 & 2 \\
\hline
\end{tabular}

Total number of companies in sample: 155.

significant differences in the presence of outliers and extreme skewness (Bowerman, O'Connell \& Murphree 2011:804). The Kruskal-Wallis test was used to compare the differences in reporting between the different sectors. The Mann-Whitney $\mathrm{U}$ test was used to compare the differences in reporting between companies that are part of the SRI Index and companies that are not.

The final research objective of this article is to investigate the preparation efforts of South African organisations for the impending carbon tax. To determine the results for this objective, the results from the statistical tests and qualitative information from the content analysis were combined. The Kruskal-Wallis test was applied to determine whether there are differences in the mean frequencies of keywords related to the carbon tax between the selected sectors. The MannWhitney $U$ test was used to ascertain whether there are significant differences between the mean frequencies of these keywords involving companies listed on the SRI Index with those that are not. If the $p$-values of these tests were smaller

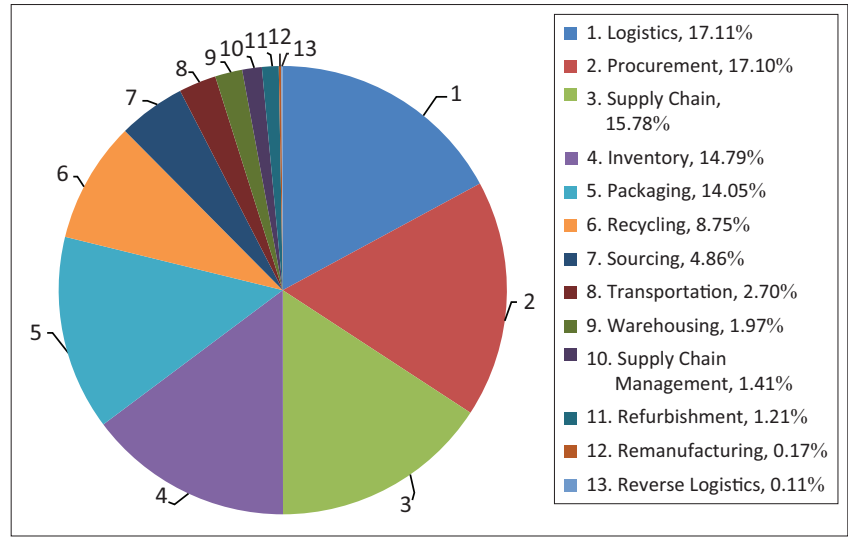

FIGURE 1: Relative frequency of supply chain keywords.

than 0.05 , it indicated that there are significant differences in the mean frequencies of carbon tax related keywords between the selected sectors and companies listed on the SRI Index and those that are not.

\section{Results and discussion Descriptive statistics}

With reference to the first objective of the article, which is to investigate the supply chain sustainability reporting practices of South African organisations, the results show that supply chain-related keywords are included in most of the sustainability and integrated annual reports that were analysed. The concepts of 'inventory', 'procurement', 'supply chain' and 'logistics' are mentioned by at least $68 \%$ of the 155 companies included in the study, as shown in Table 2.

The concepts 'logistics', 'procurement', 'supply chain', 'inventory' and 'packaging' are the supply chain-related terms mentioned most frequently in the study. 'Remanufacturing' and 'reverse logistics' were the concepts with the lowest observations and the smallest frequencies. The relative frequencies of the supply chain-related keywords are shown in Figure 1.

It appears that there is a larger range in the number of observations for sustainability-related keywords when compared with supply chain-related keywords. The concepts 'energy' and 'sustainability' have the highest number of observations and the highest frequencies by a large margin. 'Sustainability' is discussed by $97 \%$ of companies included in the study and is mentioned over 5000 times, whilst 'energy' is discussed by $90 \%$ of companies and is mentioned over 3000 times. Other concepts mentioned frequently include 'GRI', 'ISO', 'environmental management', 'carbon footprint' and 'renewable energy'. 'International Organisation for Standardisation', 'sustainability framework', 'sustainability metrics' and 'ISO 14001 certification' were the sustainabilityrelated concepts with the lowest observations and the smallest frequencies. The number of companies (out of the total of 155) and the frequency with which each sustainabilityrelated keyword was mentioned is summarised in Table 3 and Figure 2, respectively. 
TABLE 3: Number of companies that mentioned each of the sustainabilityrelated keywords.

\begin{tabular}{lcc}
\hline Sustainability keywords & $\begin{array}{c}\text { Number of } \\
\text { companies }\end{array}$ & $\begin{array}{c}\text { Percentage of total } \\
\text { number of companies }\end{array}$ \\
\hline Sustainability & 150 & 97 \\
Energy & 139 & 90 \\
Environmental management & 90 & 58 \\
International Organisation for & 86 & 55 \\
Standardisation (ISO) & 83 & 54 \\
Carbon footprint & 77 & 50 \\
Global Reporting Initiative (GRI) & 61 & 39 \\
Carbon emissions & 47 & 30 \\
ISO 14001 & 45 & 29 \\
Renewable energy & 34 & 22 \\
Carbon tax & 30 & 19 \\
Energy efficiency & 14 & 9 \\
Triple bottom line & 10 & 6 \\
Energy conservation & 10 & 6 \\
\hline Environmental performance indicators & 9 & 6 \\
GRI guidelines & 7 & 5 \\
Sustainability framework & 5 & 3 \\
ISO 14000 & 3 & 2 \\
ISO 14001 certification & 2 & 1 \\
\hline Sustainability metrics & & \\
\hline Tota number companies & & \\
\hline
\end{tabular}

Total number of companies in sample: 155 .

\section{Kruskal-Wallis test: Sector comparison}

The results of the Kruskal-Wallis test show that the mean frequencies for the majority of the keywords did not have significant differences between the sectors. 'Procurement', 'sourcing' and 'supply chain' were the supply chain-related keywords with significant differences in the mean frequencies of the sectors, and 'energy', 'Global Reporting Initiative' and 'ISO' were the sustainability-related keywords with significant differences in the mean frequencies of the sectors. All of these keywords had $p$-values of less than 0.01 except for 'Global Reporting Initiative', which had a $p$-value of 0.04 .

With regard to the significant supply chain-related concepts, 'consumer goods' and 'retailers' were the sectors with the highest mean frequencies. The consumer goods sector had the highest mean frequency for 'procurement' and for 'sourcing', whilst retailers had the highest mean frequency for 'supply chain'. With regard to the significant sustainabilityrelated concepts, the basic materials sector had the highest mean frequencies on average. Basic materials had the highest mean frequency for 'energy' and also for 'Global Reporting Initiative'. For the concept of 'ISO', consumer goods had the highest mean frequency. The mean frequencies and $p$-values for the supply chain and sustainability-related keywords are shown in Tables 4 and 5.

Table 6 shows the cases where there were significant differences in the mean frequencies of keywords between sectors. For the keyword 'supply chain', the industrials sector has a lower mean frequency (6.857) compared to the consumer goods sector (12.438) and retailers (14.950). The industrials sector (5.408) also has a significantly lower mean frequency compared to the retailers sector (10.714) for 'inventory'. The consumer goods sector (14.947) has a significantly higher mean frequency for 'procurement' compared with the industrials sector (6.978) and the retailers

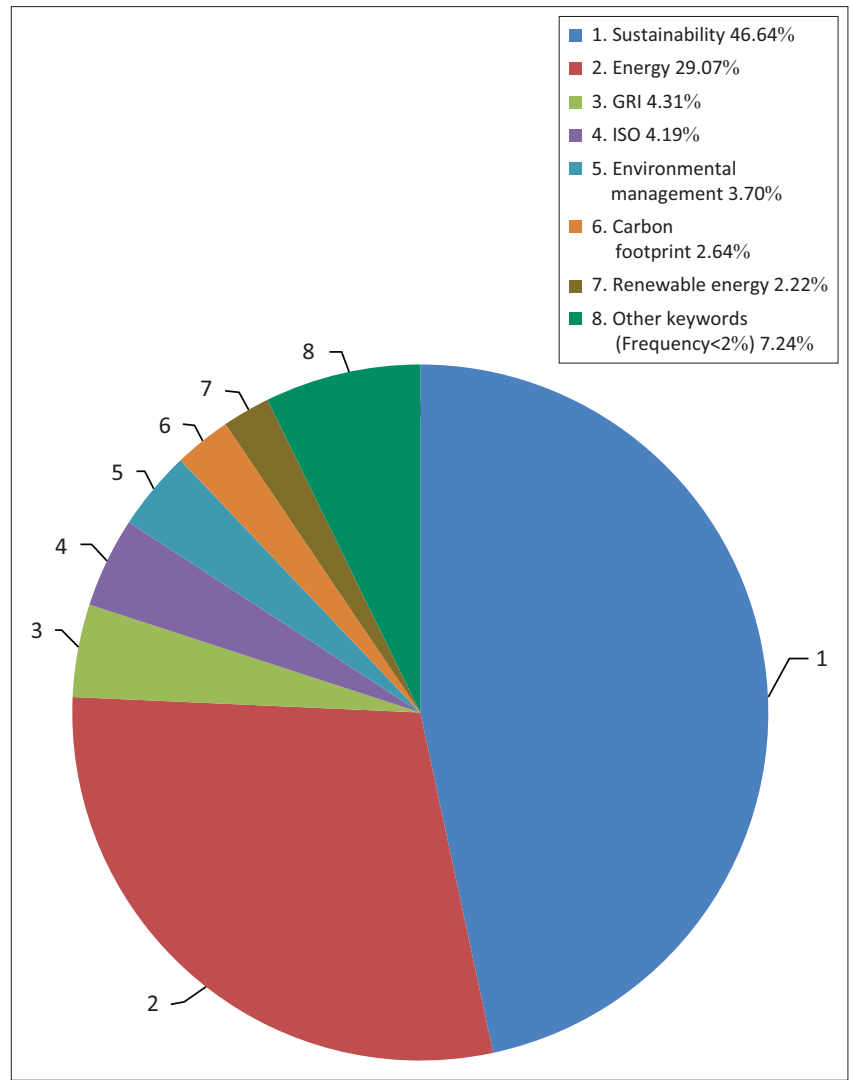

FIGURE 2: Relative frequency of sustainability-related keywords.

sector (6.789). With regard to 'sourcing', the retailers sector (6.250) has a significantly higher mean frequency compared to basic materials (1.909) and industrials (2.000). 'Energy' and 'ISO' were the only sustainability-related keywords to have significant differences between some of the sectors. Basic materials (36.630) had a significantly higher mean frequency for 'energy' when compared with the industrials sector (15.760). For the keyword 'ISO', there were significant differences in mean frequencies between all of the sectors. The retailers sector (1.286) had the lowest mean frequency compared with basic materials (4.586), industrials (6.057) and consumer goods (6.600).

These results show that consumer goods manufacturers and retailers are giving critical consideration to their sourcing and/or procurement activities to minimise input costs and are considering the impact of the supply chain on their operations. It is logical that the basic materials sector would have the highest focus on energy because of the energyintensive nature of their operations and the extensive listing requirements for mining companies included in the sector. These results also revealed that the retail sector is less concerned with energy and international standards such as ISO when compared with the other sectors.

\section{Mann-Whitney U test: Socially Responsible Investment Index versus Non-Socially Responsible Investment Index}

Table 7 displays the results of the Mann-Whitney U Test to determine whether there is a significant difference between 
TABLE 4: Kruskal-Wallis sector comparison of sustainability keywords.

\begin{tabular}{|c|c|c|c|c|c|}
\hline \multirow[t]{2}{*}{ Supply chain keywords } & \multirow{2}{*}{$\begin{array}{c}\text { Kruskal-Wallis: } \\
p \text {-value }\end{array}$} & \multicolumn{4}{|c|}{ Mean frequencies } \\
\hline & & Basic materials & Industrials & Consumer goods & Retailers \\
\hline Inventory & 0.0501 & 8.842 & 5.408 & 7.188 & 10.714 \\
\hline Logistics & 0.1000 & 3.966 & 16.317 & 11.588 & 5.105 \\
\hline Packaging & 0.2500 & 17.357 & 15.815 & 9.375 & 5.583 \\
\hline Procurement & 0.0000 & 8.795 & 6.978 & 14.947 & 6.789 \\
\hline Recycling & 0.6000 & 6.000 & 6.657 & 4.800 & 4.714 \\
\hline Refurbishment & 0.6600 & 3.000 & 1.500 & 2.400 & 4.250 \\
\hline Sourcing & 0.0000 & 1.909 & 2.000 & 6.857 & 6.250 \\
\hline Supply chain & 0.0000 & 7.414 & 6.857 & 12.438 & 14.950 \\
\hline Supply chain management & 0.8000 & 2.818 & 2.308 & 2.000 & 1.714 \\
\hline Transportation & 0.2800 & 2.700 & 4.087 & 1.200 & 1.778 \\
\hline Warehousing & 0.2300 & 1.875 & 3.000 & 1.375 & 4.750 \\
\hline
\end{tabular}

Source: Niehaus, G., 2016, Investigating the current supply chain sustainability reporting practices of South African organisations, Published Master's thesis, Stellenbosch University, Stellenbosch, p. 83

TABLE 5: Kruskal-Wallis sector comparison of sustainability keywords.

\begin{tabular}{|c|c|c|c|c|c|}
\hline \multirow[t]{2}{*}{ Sustainability keywords } & \multirow{2}{*}{$\begin{array}{c}\text { Kruskal-Wallis: } \\
p \text {-value }\end{array}$} & \multicolumn{4}{|c|}{ Mean frequencies } \\
\hline & & Basic materials & Industrials & Consumer goods & Retailers \\
\hline Carbon emissions & 0.9200 & 3.056 & 2.850 & 2.786 & 2.778 \\
\hline Carbon footprint & 0.2200 & 2.560 & 3.138 & 4.857 & 4.133 \\
\hline Carbon tax & 0.3800 & NA & NA & NA & NA \\
\hline Energy & 0.0000 & 36.630 & 15.760 & 21.053 & 11.292 \\
\hline Energy conservation & 0.4100 & 1.600 & 1.000 & NA & 1.000 \\
\hline Energy efficiency & 0.7200 & 3.182 & 1.667 & 1.800 & 4.000 \\
\hline Environmental management & 0.1600 & 5.500 & 3.536 & 3.467 & 2.333 \\
\hline Environmental performance indicators & 0.4700 & 1.000 & NA & 1.25 & 1.000 \\
\hline Global Reporting Initiative & 0.0400 & 2.680 & 2.143 & 1.833 & 1.600 \\
\hline ISO & 0.0000 & 4.586 & 6.057 & 6.600 & 1.286 \\
\hline ISO 14001 & 0.6100 & 3.000 & 3.632 & 2.778 & NA \\
\hline Renewable energy & 0.4700 & 3.571 & 6.455 & 6.429 & 1.500 \\
\hline Sustainability & 0.3500 & 35.388 & 32.561 & 37.150 & 29.625 \\
\hline
\end{tabular}

Source: Niehaus, G., 2016, Investigating the current supply chain sustainability reporting practices of South African organisations, Published Master's thesis, Stellenbosch University, Stellenbosch, p. 83 ISO, International Organisation for Standardisation; NA, not applicable.

TABLE 6: Significant differences between sectors.

\begin{tabular}{lllc}
\hline Keywords & Sector $\mathbf{1}$ & Sector $\mathbf{2}$ & Kruskal-Wallis $\boldsymbol{p}$-value \\
\hline Supply chain & Industrials & Consumer goods & 0.0167 \\
Supply chain & Industrials & Retailers & 0.0003 \\
Inventory & Industrials & Retailers & 0.0428 \\
Procurement & Industrials & Consumer goods & 0.0079 \\
Procurement & Retailers & Consumer goods & 0.0242 \\
Sourcing & Basic materials & Retailers & 0.0033 \\
Sourcing & Industrials & Retailers & 0.0034 \\
Energy & Industrials & Basic materials & 0.0235 \\
ISO & Retailers & Basic materials & 0.0330 \\
ISO & Retailers & Industrials & 0.0046 \\
ISO & Retailers & Consumer goods & 0.0108 \\
\hline
\end{tabular}

Source: Niehaus, G., 2016, Investigating the current supply chain sustainability reporting practices of South African organisations, Published Master's thesis, Stellenbosch University, Stellenbosch, p. 84

ISO, International Organisation for Standardisation.

the mean frequencies of SRI Index companies and non-SRI Index companies listed on the JSE. When there were fewer than five observations no mean frequency was calculated, resulting in the display of 'NA'. The results show that the mean frequencies for the majority of the keywords did not have significant differences between SRI Index and non-SRI Index companies. 'Procurement', 'recycling' and 'supply chain' were the supply chain-related keywords with significant differences, and 'energy', 'environmental management' and 'sustainability' were the sustainability-related keywords with significant differences. 'Recycling', 'supply chain', 'energy' and 'sustainability' all had $p$-values of less than 0.01 , 'procurement' had a $p$-value of 0.0219 and 'environmental management' had a $p$-value of 0.0121 .

Socially Responsible Investment Index companies had significantly higher mean frequencies than non-SRI Index companies for all of the significant keywords. The mean frequency for 'procurement' for SRI Index companies is 10.894 compared with 7.434 for non-SRI Index companies, and for 'recycling' for SRI Index companies the mean frequency is 7 compared with 5.246 for non-SRI Index companies. The difference in mean frequency for 'supply chain' is large at 14.581 for SRI Index companies, compared with 5.844 for non-SRI Index companies.

For the significant sustainability-related keywords, the mean frequencies for non-SRI Index companies are roughly half of those for the SRI Index companies. This is in line with the fact that SRI Index companies have an obligation to ensure that they maintain a high level of social and environmental performance. To illustrate this, the mean frequency for 'energy' for SRI Index companies is 32.140 compared with 17.270 for non-SRI Index companies. The mean frequency for 'environmental management' for SRI Index companies is 6.194 compared with 3.525 for non-SRI Index companies. The 
TABLE 7: Socially Responsible Investment Index comparison: Mann-Whitney $\mathrm{U}$ test results.

\begin{tabular}{lccc}
\hline Variable & $\begin{array}{c}\text { Mann-Whitney } \\
\text { U test: } \boldsymbol{p} \text {-value }\end{array}$ & $\begin{array}{c}\text { SRI Index mean } \\
\text { frequency }\end{array}$ & $\begin{array}{c}\text { Non-SRI Index } \\
\text { mean frequency }\end{array}$ \\
\hline Inventory & 0.3429 & 7.744 & 7.506 \\
Logistics & 0.1058 & 14.769 & 7.493 \\
Packaging & 0.8872 & 18.793 & 8.550 \\
Procurement & 0.0219 & 10.894 & 7.434 \\
Recycling & 0.0013 & 7.000 & 5.246 \\
Refurbishment & 0.6120 & 2.667 & 3.385 \\
Sourcing & 0.1843 & 5.788 & 2.578 \\
Supply chain & 0.0000 & 14.581 & 5.844 \\
Supply chain management & 0.6345 & 2.313 & 2.261 \\
Transportation & 0.8007 & 3.167 & 2.849 \\
Warehousing & 0.6346 & 3.000 & 2.680 \\
Carbon emissions & 0.5332 & 2.839 & 2.933 \\
Carbon footprint & 0.9208 & 3.314 & 3.521 \\
Carbon tax & 0.2543 & 3.950 & 2.571 \\
\hline Energy & 0.0000 & 32.140 & 17.270 \\
Energy conservation & 0.4161 & $\mathrm{NA}$ & $\mathrm{NA}$ \\
\hline Energy efficiency & 0.8858 & 2.474 & 2.909 \\
Environmental management & 0.0121 & 6.194 & 3.525 \\
Environmental performance & 0.4237 & 1.000 & 1.200 \\
indicators & & & \\
Global Reporting Initiative & 0.3897 & 2.242 & 2.167 \\
ISO & 0.9042 & 5.088 & 5.385 \\
ISO 14001 & 0.6036 & 3.417 & 3.000 \\
Renewable energy & 0.1669 & 6.750 & 4.200 \\
\hline Sustainability & 0.0000 & 50.820 & 25.030 \\
Triple bottom line & 0.3354 & $\mathrm{NA}$ & $\mathrm{NA}$ \\
\hline Source: Niens, & & & \\
\hline
\end{tabular}

Source: Niehaus, G., 2016, Investigating the current supply chain sustainability reporting practices of South African organisations, Published Master's thesis, Stellenbosch University, Stellenbosch, p. 87

SRI, Socially Responsible Investment; ISO, International Organisation for Standardisation; NA, not applicable.

greatest difference in mean frequencies is for 'sustainability', with SRI Index companies at 50.820 and non-SRI Index companies at 25.030. From the results, it is clear that SRI Index companies discuss supply chain and sustainabilityrelated concepts more than non-SRI Index companies.

\section{Preparation efforts for the impending carbon tax}

The final objective for this article is to investigate preparation efforts by South African organisations for the impending carbon tax. Three keywords were included in the research for this article, which relate to the concept of carbon tax, namely, 'carbon emissions', 'carbon footprint' and 'carbon tax'. Although none of these keywords had significant results for the sector comparison and the SRI Index and non-SRI Index comparison, the absolute frequencies can be used as an indication of the level of awareness of these concepts in South African organisations.

Figure 3 shows the sector contribution to the total frequency for the three keywords, namely, 'carbon emissions', 'carbon footprint' and 'carbon tax'. The industrials sector had the highest contribution to the total frequencies for the keywords 'carbon emissions' and 'carbon tax' at 33\% and 32\%, respectively. Basic materials contributed $31 \%$ to the total frequency for the keyword 'carbon emissions' and the retail sector contributed the least at $14 \%$. The consumer goods sector contributed $24 \%$ to the keyword 'carbon footprint' and

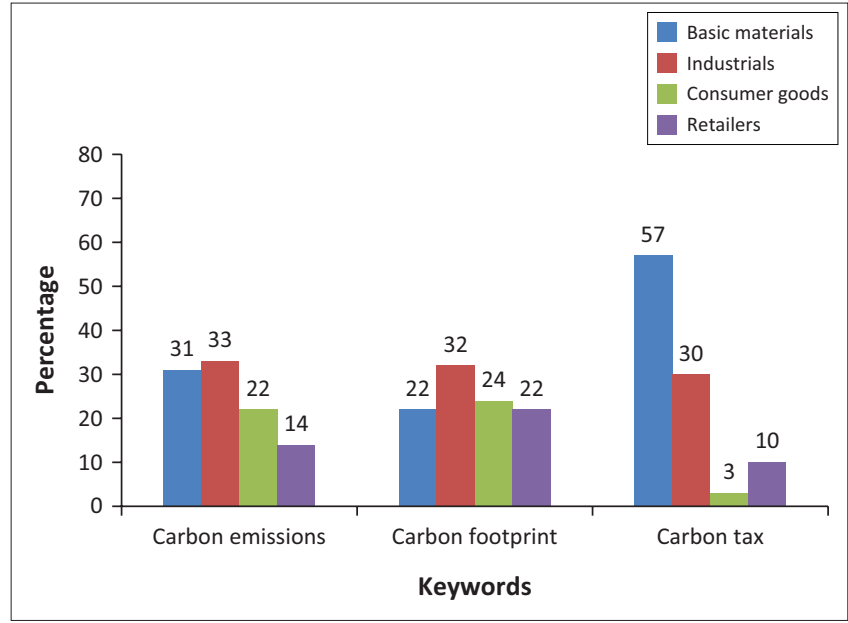

Source: Niehaus, G., 2016, Investigating the current supply chain sustainability reporting practices of South African organisations, Published Master's thesis, Stellenbosch University, Stellenbosch, p. 89

FIGURE 3: Sector contribution to carbon emissions, carbon footprint and carbon tax.

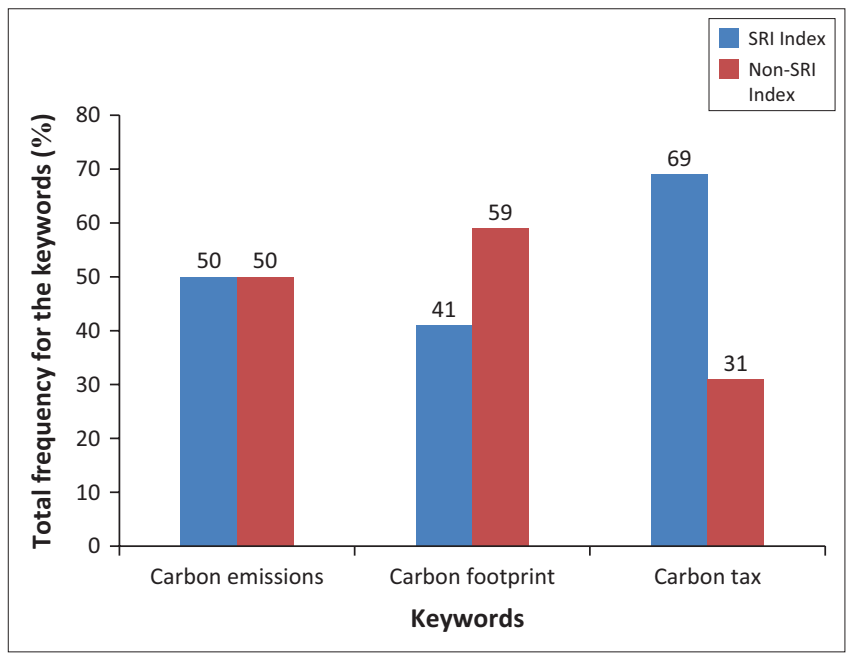

Source: Niehaus, G., 2016, Investigating the current supply chain sustainability reporting practices of South African organisations, Published Master's thesis, Stellenbosch University, Stellenbosch, p. 91

FIGURE 4: Socially Responsible Investment Index and Non-Socially Responsible Investment Index contribution to carbon emissions, carbon footprint and carbon tax.

basic materials and the retail sector each contributed $22 \%$. For the keyword 'carbon tax', the basic materials sector had by far the highest contribution at $57 \%$, followed by the industrials sector at $30 \%$. The consumer goods sector had by the far the lowest contribution at 3\% followed by the retail sector at $10 \%$.

From the results, it can be concluded that the basic materials and industrials sectors are aware of the concepts relating to the impending carbon tax and discuss them regularly. Although the consumer goods and retail sectors are aware of these concepts given their inclusion in the annual reports, there is room for greater discussion, particularly with regard to the keywords 'carbon emissions' and 'carbon tax'.

Figure 4 shows the contribution of the SRI Index and non-SRI Index companies to the total frequency for the keywords 'carbon emissions', 'carbon footprint' and 'carbon tax'. 
Companies in the SRI Index and companies in the non-SRI Index mentioned the keyword 'carbon emissions' equally with a 50:50 split in the contribution. For the keyword 'carbon footprint', companies not included in the SRI Index contributed $59 \%$ to the total frequency with the remaining $41 \%$ contribution coming from companies in the SRI Index. With regard to 'carbon tax', companies in the SRI Index had the highest contribution at $69 \%$ compared with the $31 \%$ contribution from companies not included in the SRI Index.

In summary, the contributions of companies in the SRI Index and companies not included in the SRI Index differ for each of the keywords. The split in contributions of 50:50 is unexpected as there are fewer companies included in the SRI Index. That being said, the greatest difference in contributions is for the keyword carbon tax and there is much room for improvement by companies not included in the SRI Index.

\section{Conclusion}

The results of this study show that the majority of companies included in the sample do mention supply chain and sustainability concepts; however, there were no significant differences between sectors for the majority of the keywords. The most frequently mentioned supply chain concepts were 'logistics', 'procurement' and 'supply chain', which is a positive indication that organisations are considering the impact of their supply chain operations with a particular focus on sourcing and procurement practices.

The consumer goods and retail sectors had significantly higher mean frequencies than the industrials and basic materials sectors for supply chain-related concepts. 'Energy' and 'sustainability' were mentioned most frequently of all of the concepts; however, there was no significant difference in the mention of 'sustainability' between sectors. Basic materials and the industrials sector had significantly higher mean frequencies for the sustainability-related terms 'energy' and 'ISO'. When comparing SRI Index companies and nonSRI Index companies, it is clear that there were no significant differences for the majority of the keywords. The concepts that produced significant results include 'procurement', 'recycling', 'supply chain', 'energy', 'environmental management' and 'sustainability', and the SRI Index companies had significantly higher mean frequencies for all of these concepts.

It is important to note that although supply chain and sustainability concepts are discussed in sustainability and integrated annual reports, there is limited discussion on important sustainable supply chain concepts such as reverse logistics, refurbishment and remanufacturing. These practices can facilitate organisations in reducing emissions, mitigating negative environmental impacts and minimising costs. There was also limited discussion on carbon emissions, carbon footprints and the impending carbon tax. This is a cause for concern as organisations need to begin managing and reducing their carbon footprints and greenhouse gas emissions to mitigate the financial impact of the carbon tax.
South African organisations need to increase their focus on sustainable supply chain practices particularly given the current economic climate and the global shift towards sustainable development.

The research showed that companies are discussing important concepts relating to the implementation of the impending carbon tax. It is an indication that the required changes are being discussed (at the very least), which suggests a move in the right direction towards decarbonising supply chains.

\section{Recommendations for future research}

Further research on this topic is warranted to support the findings of this article. It would be beneficial to include all sectors of the economy to produce more representative results and the cooperation of privately owned companies is necessary to gather enough data to achieve a significant number of observations. Performing qualitative research in the form of in-depth interviews and focus groups with relevant industry members would provide detailed information on the exact nature of supply chain operations and the extent to which sustainable practices are implemented. Gaining further industry support in the form of participation in online questionnaires would provide further details from a larger sample, thus producing more generalisable results. Given the relatively low level of discussion on concepts relating to carbon emissions and the impending implementation of the carbon tax in South Africa, further investigation into the preparation efforts of companies to reduce their emissions and mitigate the impact of the tax is necessary.

\section{Limitations of the study}

There are six noteworthy limitations highlighted for this study. Firstly, there are limited comprehensive sources of information on the supply chain sustainability practices of South African organisations. Secondly, there is a lack of data available from private companies, which led to the decision to make use of public organisations listed on the JSE. Thirdly, there were limitations with regard to time and monetary resources. These resource limitations contributed to the decision to use public organisations with readily available data as opposed to contacting private organisations and obtaining proprietary data. Fourthly, not all of the companies listed in the sectors included in the study had appropriate data available, as some of the annual reports were too old (prior to 2012) or not available from the company websites. Fifthly, a small number of reports could not be exported into the NVivo 10 software analysis program and were therefore excluded from the study. Lastly, a number of pre-selected variables (keywords or phrases) had too few observations to have any statistical relevance and as a result they were excluded from the study.

\section{Acknowledgements}

The authors would like to acknowledge Professor Daan Nel from Stellenbosch University for his assistance with the 
statistical analyses and Professor James R. Stock from the University of South Florida for his contribution to this study.

\section{Competing interests}

The authors declare that they have no financial or personal relationships that may have inappropriately influenced them in writing this article.

\section{Authors' contributions}

G.N. conducted the research for her Master's thesis and coauthored the article. H.W.F. acted as the supervisor for the Master's thesis and co-authored the article. L.L.G-G. acted as the co-supervisor of the Master's thesis and co-authored the article.

\section{References}

Alton, T., Arndt, C., Davies, R., Hartley, F., Makrelov, K., Thurlow, J. et al., 2014, 'The economic implications of introducing carbon taxes in South Africa', Applied Energy 116, 344-354

Babin, B.J. \& Zikmund, W.G., 2010, Exploring marketing research, South-Western Cengage Learning, China.

Bonini, S., Görner, S. \& Jones, A., 2010, How companies manage sustainability: McKinsey Global Survey results, viewed 05 November 2017, from https://www. mckinsey.com/business-functions/sustainability-and-resource-productivity/ourmckinsey.com/business-functions/sustainability-and-resource-productivity/our-
insights/how-companies-manage-sustainability-mckinsey-global-survey-results

Bowerman, B.L., O'Connell, R.T. \& Murphree, E.S., 2011, Business statistics in practice, McGraw-Hill/Irwin, New York.

Brown, B.J., Hanson, M.E., Liverman, D.M. \& Merideth, R.W., 1987, ‘Global sustainability: Toward definition', Environmental Management 11(6), 713-719. https://doi.org/10.1007/BF01867238

Carbon Disclosure Project (CDP), 2013a, The South African business response to climate change: Is it delivering the required performance?, viewed 22 April 2014, from http://www.nbi.org.za/Lists/Publications/Attachments/360/CDP_Report_2013. pdf

Carbon Disclosure Project (CDP), 2013b, The South African business response to climate change: Is it delivering the required performance? CDP South Africa 100 Climate Change Report 2013, viewed 14 September 2014, from https://www.cdp. net/CDPResults/CDP-South-Africa-Climate-Change-Report-2013.pdf

Carter, C.R. \& Rogers, D.S., 2008, 'A framework of sustainable supply chain management: Moving toward new theory', International Journal of Physical Distribution and Logistics Management 38(5), 360-387. https://doi.org/10.1108/ 09600030810882816

Ellram, L.M., Kirchoff, J.F. \& Tate, W.L., 2009, 'Corporate social responsibility reports: A thematic analysis related to supply chain management', Journal of Supply Chain Management 46(1), 19-44.

Espinosa, J.A. \& Stock, J.R., 2017, 'Exploring current conditions and challenges in sustainability reporting involving supply chain management issues: Evidence from sustainability reporting involving supply chain management issues: Evidence from Management Professionals Educator's Conference, San Diego, CA, September 27 Management Professionals Educator's Conference, San Diego,
Operations Management in the Supply Chain Track, pp. 18-19.

Fisher-Kowalski, M., 2011, 'Analysing sustainability transitions as a shift between socio-metabolic regimes', Environmental Innovation and Societal Transitions 1 152-159.

Giamporcaro, S. \& Pretorius, L., 2012, 'Sustainable and responsible investment (SRI) in South Africa: A limited adoption of environmental criteria', Investment Analysts Journal 41(75), 1-19.

Gordhan, P., 2013, '2013 Budget speech', viewed 13 March 2014, from http://www. treasury.gov.za/documents/national\%20budget/2013/speech/speech.pdf

Gray, R., 2010, 'Is accounting for sustainability actually accounting for sustainability ... and how would we know? An exploration of narratives of organisations and the planet', Accounting, Organizations and Society 35, 47-62.

Greve, N., 2014, 'Carbon tax postponed to 2016', Engineering News, viewed 13 March 2014, from http://www.engineeringnews.co.za/article/carbon-tax-postponedto-2016-2014-02-26

Handfield, R., Sroufe, R. \& Walton, S., 2005, 'Integrating environmental management and supply chain strategies', Business Strategy and the Environment 14(1), 1-19. https://doi.org/10.1002/bse.422

Hanks, J. \& Gardiner, L., 2012, Private sector opinion - Integrated reporting: Lessons from the South African experience, A Global Corporate Governance Forum from the South African experience, A Global Corporate Governance
Publication. Issue 25, International Finance Corporation, Washington, DC.
Heal, G., 2012, 'Reflections - Defining and measuring sustainability', Review of Environmental Economics and Policy 6(1), 147-163. https://doi.org/10.1093/ reep/rer023

Hitchcock, T., 2012, 'Low carbon and green supply chains: The legal drivers and commercial pressures', Supply Chain Management: An International Journal 17(1), 98-101. https://doi.org/10.1108/13598541211212249

Ho, Y. \& Lin, C., 2008, 'An empirical study on logistics service providers' intention to adopt green innovations', Journal of Technology Management and Innovation $3(1), 17-26$

Incite Sustainability, 2009, Carbon disclosure project 2009 South Africa JSE 100 viewed 23 September 2017, from http://www.nbi.org.za/wp-content/ uploads/2016/06/CDP-2009-South-Africa-JSE-100-Report.pdf

Inglesi-Lotz, R., 2015, 'SA needs to transition to a less energy-intensive economy', Rand Daily Mail, viewed 01 August 2015, from http://www.rdm.co.za/ business/2015/07/07/sa-needs-to-transition-to-a-less-energy-intensive-economy

Jamali, D., Mezher, T. \& Bitar, H., 2006, 'Corporate social responsibility and the challenge of triple bottom line integration: Insights from the Lebanese context', International Journal of Environment and Sustainable Development 5(4), 395414. https://doi.org/10.1504/IJESD.2006.011557

JSE, 2014, Main board, viewed 13 March 2014, from http://www.jse.co.za/How-ToList/Main-Board.aspx

JSE, 2015, SRI index constituents for 2014, viewed 01 August 2015, from http://www. jse.co.za/About-Us/SRI/Constituents/SRIIndexConstituents2013.aspx

Kinderytè, L., 2008, 'Analysis and comparison of methodologies for corporate sustainability assessment', Environmental Research, Engineering \& Management 46(4), 66-75.

Koshkaki, M., Gammelgaard, B. \& Stock, J., 2017, 'Sustainability reporting A comparative study of supply chain practices', in D. Hellström, J. Kembro \& H. Bodner (eds.), Proceedings of the 29th NOFOMA Conference 'Taking on Grand Challenges', pp. 1-10, Lund University, Lund.

KPMG, 2013, The KPMG survey of corporate responsibility reporting 2013, viewed 08 March 2014, from http://www.kpmg.com/global/en/issuesandinsights/ articlespublications/corporate-responsibility/pages/corporate-responsibilityreporting-survey-2013.aspx

Kreie, A. \& McKinnon, A., 2010, 'Adaptive logistics: Preparing logistical systems for climate change', in Logistics Research Network Conference in Harrogate, HeriotWatt University, Edinburgh, pp. 8-10, 8th-10th September.

Kumar, S., Teichman, S. \& Timpernagel, T., 2011, 'A green supply chain is a requirement for profitability', International Journal of Production Research 50(5), 1278-1296. https://doi.org/10.1080/00207543.2011.571924

Media Club South Africa, 2015, South Africa's economy: Key sectors, viewed 01 August 2015, from http://www.mediaclubsouthafrica.com/component/content/ article?id=111:sa-economy-key-sectors

Mefford, R.N., 2011, 'The economic value of a sustainable supply chain', Business and Society Review 116(1), 109-143. https://doi.org/10.1111/j.1467-8594.2011. 00379.x

Minx, J. \& Wiedmann, T., 2007, A definition of 'carbon footprint, viewed 09 September 2016, from http://books.google.co.za/books?hl=en\&lr=\&id=GCkU1p_6HNwC\&oi=
fnd\&pg=PA1\&dq=minx+and+wiedmann\&ots=D-zVHK8IOm\&sig=wN8rSspLyUB7r

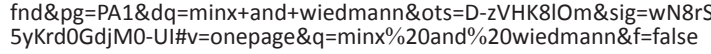

Morhardt, J.E., 2009, 'Corporate social responsibility and sustainability reporting on the Internet', Business Strategy and the Environment 19(7), 436-452. https://doi. org/10.1002/bse.657

Niehaus, G., 2016, Investigating the current supply chain sustainability reporting practices of South African organisations, Published Master's thesis, Stellenbosch practices of South African
University, Stellenbosch.

Nguyen, T. \& Stock, J.R., 2017, 'Supply chain management sustainability practices of Vietnamese firms', in 2017 POMS Annual Conference, 1-10, Seattle, WA, 5th-8th May.

SAICA, 2011, An integrated report is a new requirement for listed companies, viewed 13 March 2014, from https://www.saica.co.za/tabid/695/itemid/2344/language/ en-ZA/An-integrated-report-is-a-new-requirement-for-list.aspx

Tran, T., 2015, Corporate social responsibility and profits: A trade-off or a balance? viewed 10 July 2017, from http://cddrl.fsi.stanford.edu/sites/default/files/thuy tran_cddrl_thesis_v3.pdf

Van Marrewijk, M. \& Werre, M., 2003, 'Multiple levels of corporate sustainability', Journal of Business Ethics 44(2-3), 107-119.

Van Zyl, A.S., 2013, 'Sustainability and integrated reporting in the South African corporate sector', Journal of Sustainability Management 1(1), 19-42. https://doi. org/10.19030/iber.v12i8.7988

Wang, Z., Stock, J. \& Li, S., 2015, 'Supply chain management sustainability practices in Chinese service firms: A content analysis of CSR reports', Journal of Academy of Business and Economics 15(4), 71-76. https://doi.org/10.18374/JABE-15-4.7

Winkler, H. \& Marquard, A., 2011, 'Analysis of the economic implications of a carbon tax', Journal of Energy Southern Africa 22(1), 55-68.

World Economic Forum, 2009, Supply chain decarbonisation: The role of logistics and transport in reducing supply chain carbon emissions, viewed 27 February 2014 from http://www3.weforum.org/docs/WEF_LT_SupplyChainDecarbonization Report_2009.pdf 